\title{
The Effect of Problem-Based Flipped Learning and Academic Procrastination on Students' Critical Thinking in Learning Physics in High School
}

\author{
I Wayan Santyasa*, Ketut Agustini, I Made Tegeh \\ Universitas Pendidikan Ganesha \\ Bali, Indonesia \\ *santyasa@undiksha.ac.id, ketutagustini@undiksha.ac.id,im-tegeh@undiksha.ac.id
}

\begin{abstract}
Learning physics in SMA cannot be separated from students' critical thinking activities without delay. Critical thinking will not develop optimally if the learning still tolerates the direct learning model. One of the learning models that are accommodative in developing critical thinking is the problembased learning model. Both models can be used as pedagogical content for flipped learning, which is termed problem-based flipped learning (PBFL) and direct flipped learning (DFL). This study aims at describing the difference effect between PBFL and DFL on critical thinking (CT) viewed from students' academic procrastination (AP) in learning physics in SMA. Student's AP is a variable of sorting critical thinking skills based on low AP (LAP) and high AP (HAP). The study population was 6 classes of students of class XI SMAN 2 Semarapura. A sample of 4 classes was selected by random assignment technique, which then randomized again to determine 2 classes as PBFL class and 2 classes as DFL class. To collect the students' academic procrastination, the questionnaire is used. Students' critical thinking skills were collected by means of an essay test using a 4point scale. Data were analyzed using two-way ANACOVA with initial critical thinking skills scores as covariates. Hypothesis testing is carried out at the $5 \%$ significance level. The results showed 1) There was a significant difference in the effect between PBFL and DFL on CT $(F=11,769 ; p<0.05)$. Students' $C T$ was higher achieved by students who studied with PBFL than them studied in the DFL model. 2) There is a significant difference in the effect between LAP and HAP on CT $(F=7.006 ; p<0.05)$. Higher CT rates were achieved by students who had LAP compared with them had HAP. 3) There is no significant interactive effect between the learning model and AP on CT (F = 1.451; p> 0.05). In learning physics class XI SMA, the two AP categories are accommodating to the PBFL and DFL models.
\end{abstract}

Keywords-problem-based flipped learning, direct flipped learning, critical thinking

\section{INTRODUCTION}

Now education has long entered the 21 st century. No exception for learning physics in high school. Physics education and learning in this century really need output in the form of specific learning skills. These learning skills include critical thinking skills, problem solving, creative thinking skills, communication, and collaborative thinking [1]. In high school physics learning, these abilities are inevitable for students to achieve. At the same time, students are also led to master information and knowledge. Therefore, learning physics requires skills to acquire, select, and process information. These skills require critical, systematic, logical, and creative thinking [2]. Therefore, we need a physics learning program that can develop critical, systematic, logical, and creative thinking skills.

Physics education and learning in Indonesia, which provide a vehicle for students to develop thinking skills above, still have many obstacles. One of the reasons is the education system which is still focused on examinations [3]. Physics learning tends to focus on lesson content and neglects the development of students' critical thinking skills [4]. The learning model used in physics learning tends to have direct learning (DL) nuances [5]. In DL, the material is sorted in such a way and taught explicitly. This method of learning turns out to have a less than optimal impact on students in developing critical thinking skills [5]. Another fact also states that DL has a low impact on critical thinking skills, creative thinking skills, and collaborative skills among students [6]. This model is called as a conventional learning model which cannot facilitate students in developing critical thinking skills in learning physics, and resulting in low learning achievement [7].

Based on the facts that the DL model is not effective in developing critical thinking, the DL model cannot be maintained in physics learning. One alternative as a substitute is the problem-based learning (PBL) model. The PBL model is appropriate to use in learning physics [8]. PBL is a physics learning reform that can create innovation in developing a new learning atmosphere. Empirically PBL is better than the DL model in physics learning $[9,10]$. The PBL model provides a learning process to develop higher-order thinking skills such as critical thinking, problem-solving skills, and creative thinking $[10,11]$.

Related to the implementation of PBL in physics learning, it is showed very challenging findings, that although the critical 
thinking skills achieved by students learning with the PBL model were higher than the DL models, students' critical thinking skills in physics learning were produced by both models are still in the very low category and have not reached the success criteria [10]. They stated that students in the PBL model were only able to achieve critical thinking skills with $\mathrm{M}$ $=36.86 ; \mathrm{SD}=0.561$, very low category, and DL model with $\mathrm{M}$ $=33.02 ; \mathrm{SD}=0.561$, very low category. These findings indicate that the implementation of PBL in physics learning requires continuous review.

In line with the rapid development of technology today, the implementation of both PBL and DL in learning physics shoes is integrated into learning with network mode. One of them is flipped classroom learning or flipped learning (FL). The effectiveness of FL in learning various fields of study in high school has been proven by several previous research results [12-18]. The PBL model that is integrated as flipped learning (FL) pedagogy content is termed problem-based flipped learning (PBFL). The PBFL model has proven its effectiveness as a learning approach to promote learning about hyperthyroidism in the endocrinology internship [19]. In its implementation, the PBFL model is compared with the direct flipped learning (DFL) model. The effectiveness of the PBFL model in supporting the growth of critical thinking is shown by previous studies [20-23].

Physics learning has very unique and complex characteristics, which require continuous problem-solving activities, empowerment of higher order thinking skills, and metacognition. These characteristics often cause students to often delay their learning activities. The attitude of delaying doing study assignments is termed academic procrastination [24]. Academic procrastination is often the cause of student failure in achieving learning achievement $[25,26]$. They stated that a high academic procrastination has a greater chance of failure, whereas a low academic procrastination has a lower chance of failure in learning. The low academic procrastination will make students achieve higher learning achievement [27]. In learning physics class $\mathrm{X}$ senior high school, it is stated that students who have low academic procrastination show higher learning outcomes than those who have high academic procrastination [28].

Based on the problem background described above, this study proposes a problem which is formulated as follows: "Is there a difference in the effectiveness of the problem-based flipped learning model compared to the direct flipped learning model in achieving critical thinking viewed from students' academic procrastination attitudes in physics learning of class XI of the senior high school? "

\section{A. Problem-Based Flipped Learning Model}

The term problem-based flipped learning (PBFL) is a combination of two terms, namely problem-based learning (PBL) and flipped learning (FL). PBL is an accommodating learning model to develop students' critical thinking skills in learning physics [10]. The purpose of using PBL is so that students have the ability to think critically, analytically, systematically and logically to determine alternative problem solving through empirical data exploration to foster scientific attitudes [29]. PBL apart from being a facility for students to build knowledge, can also be used to improve students' problem-solving abilities, critical and creative thinking skills in learning physics [30]. PBL uses learning strategies by structuring problems designed for the acquisition of critical thinking skills, team participation skills, problem-solving skills, and independent learning strategies [31]. PBL is an independent learning, student-centered, independent style that is guided by a teacher or facilitator [32]. PBL is innovative learning that serves students as active learners [8]. In the PBL model, students are encouraged to take the initiative in building their own knowledge [33]. The PBL model provides a learning environment that empowers the potential for students' initial knowledge, because students entering the classroom have been able to present a unique and different framework for learning $[34,35]$. The characteristics of PBL have great potential for students to develop critical thinking skills in learning physics in senior high school.

The rapid development of technology today makes it possible to integrate PBL into FL with the term PBFL. The PBFL model steps are shown in Table 1.

TABLE I. PBFL MODEL STEPS [19]

\begin{tabular}{|c|c|c|}
\hline Steps & Teacher & Students \\
\hline $\begin{array}{l}\text { Before class } \\
\text { meeting }\end{array}$ & 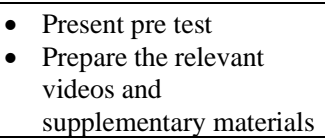 & $\begin{array}{l}\text { - Answer pre test } \\
\text { - Watch videos and read } \\
\text { material on their own } \\
\text { time }\end{array}$ \\
\hline $\begin{array}{l}\text { In class } \\
\text { meeting }\end{array}$ & 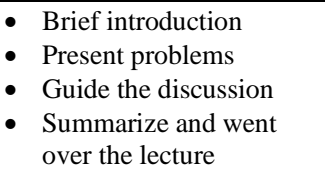 & $\begin{array}{ll}\text { - } & \text { Small group discussion } \\
\text { - } & \text { Review the main point } \\
\text { - } & \text { Solve the problems } \\
\text { - } & \text { Ask the unsolved } \\
& \text { problems }\end{array}$ \\
\hline $\begin{array}{l}\text { After class } \\
\text { meeting }\end{array}$ & $\begin{array}{ll}\text { - } & \text { Present post test } \\
\text { - } & \text { Post survey } \\
\end{array}$ & $\begin{array}{l}\text { - Answer post test } \\
\text { - } \text { Answer question }\end{array}$ \\
\hline
\end{tabular}

\section{B. Direct Flipped Learning}

The term direct flipped learning (DFL) comes from direct instruction (DI) which is integrated into flipped learning (FL). DI is affiliated with the instructional approach and curriculum materials developed by Sigmund Freud and Carl Rogers in the late 1960s [36]. Learning is carried out specifically and explicitly, based on the classic behaviorist stimulus / response / conditioning model developed by B. F. Skinner. The learning program is in the form of a linearly programmed learning model, namely the subject matter is designed step by step, a lesson-by-lesson approach that follows a predetermined sequence of skills and is then given to students through elearning. This linear learning program aims to streamline the time of students doing assignments, and to strengthen student behavior positively. The learning program which becomes elearning content is more focused on efforts to present curriculum material. Presentation of the material is followed by 
giving assignments, giving tests, and conducting assessments in accordance with the predetermined learning objectives. Evaluation results are followed by feedback for changing behavior, ability grouping, and emphasis on academic skills. Operationally, the DFL model is applied in the following stages: motivating students, delivering subject matter, forming student groups, students learning in groups, students reporting discussion results, teachers evaluating student reports.

\section{Academic Procrastination}

Academic procrastination is a type of delay that is done by students when working on formal tasks related to the academic field [37]. Solomon and Rothblum mention six academic fields to see the types of tasks that are often delayed by students [37], namely: 1) writing assignments, 2) learning assignments, 3) reading assignments, 4) doing administrative tasks, 5) attending meetings, 6) delays in overall academic performance. Milgram states that procrastination consists of four dimensions [37], namely: 1) a series of procrastination behaviors, 2) resulting in substandard behavior, 3 ) involving a number of tasks that are perceived as important for procrastinators to do, 4) resulting in an unpleasant emotional state. In summary, the dimensions and indicators of academic procrastination can be seen in Table 2 .

TABLE II. DIMENSION AND INDICATOR OF THE ACADEMIC PROCRASTINATION [38]

\begin{tabular}{|l|l|l|}
\hline No & \multicolumn{1}{|c|}{ Dimension } & \multicolumn{1}{c|}{ Indicator } \\
\hline 1 & A series of delaying behaviors & Delay in academic assignments \\
\hline 2 & Produce substandard behavior & Lags in working on tasks \\
\cline { 3 - 3 } & $\begin{array}{l}\text { Time gap between plan and } \\
\text { actual performance }\end{array}$ \\
\hline 3 & $\begin{array}{l}\text { Involves a number of tasks } \\
\text { that are perceived as important } \\
\text { for procrastinators }\end{array}$ & $\begin{array}{l}\text { Do other activities that are } \\
\text { more fun }\end{array}$ \\
\hline 4 & $\begin{array}{l}\text { Produce an unpleasant } \\
\text { emotional state }\end{array}$ & Emotional anxiety \\
\hline
\end{tabular}

\section{Critical Thinking}

Critical thinking is "sensible reflective thinking that focuses on deciding what to believe or do [39]. In deciding what to believe and do, a person is assisted by a set of critical thinking skills. When students think critically, they are encouraged to think for themselves, formulate hypotheses, analyze and synthesize events, to go further by developing new hypotheses and testing them based on empirical facts [40]. In other words, critical thinking students look like scientists who are doing research, formulating questions, rejecting such information, being active, thinking analytically and synthesis, evaluating information and explaining it properly, treating the mind that is open and aware of the thought process. Every student must have effective critical thinking skills, and they must not accept what the teacher says. Therefore, teachers must critically provide learning facilities that can encourage students to think critically.

\section{METHODS}

This study used a non-equivalent pretest posttest control group design. The study population was 6 classes of students of class XI SMAN 2 Semarapura-Klungkung-Bali. A sample of 4 classes was selected by random assignment technique, which then randomized again to determine 2 classes as experiment group, namely class XI MIPA 3 and XI MIPA 4, and 2 classes as control group namely class XI MIPA 2 and class XI MIPA 6 . This study examines one independent variable, namely the flipped learning model, which is divided into two categories, namely problem-based flipped learning (PBFL) and direct flipped learning (DFL). In addition, this study also examines one moderator variable, namely academic procrastination, which is divided into two levels, namely low academic procrastination (LAP) and high academic procrastination (HAP). The dependent variable measured was students' critical thinking skills in physics learning for class XI senior high school. The research was conducted in 5 times meetings, each meeting with a duration of 135 minutes.

Student academic procrastination data were collected using a LIKERT model questionnaire. In this study 35 items of an academic procrastination questionnaire were developed using a 4-point scale. Before being used, the questionnaire was tested in order to analyze the internal consistency of the items using the product moment correlation and its reliability was determined by using Cronbach's alpha [41]. There 31 items were obtained which were feasible to be used in the study with the distribution of item-total correlation coefficients moving from $r=0.3$ to $r=0.7$ with the criteria of 1 item with a low correlation index, 27 items with a moderate correlation index, and 3 items with high correlation index. The reliability of the 31 items of the procrastination questionnaire was 0.919 , falling into the very high category.

Students' critical thinking skills were collected by means of an essay test using a 4-point scale. First of all, 25 critical thinking items were developed. After being tested, 12 items were determined as research instruments. Based on the test results, these critical thinking skills items have a moving difference power index (DPI) from DPI $=0.25$ to DPI $=0.71$, with the criteria of 4 low DPI items, 5 medium DPI items, and 3 high DPI items. The item difficulty index (IDI) of the 12 test items moved from IDI $=0.22$ to IDI $=0.67$ with the criteria of 3 easy items, 4 moderate items, and 5 difficult items. The totalitem correlation index of the 12 items is calculated using the moment product correlation, and the results move from $r=0.31$ to $r=0.62$, with the criteria of 3 items with low correlation index, 8 items with moderate correlation index, and 1 item with high correlation index. The 12-item reliability index of the critical thinking skills test was analyzed using Cronbach's alpha, and the result was Cronbach's alpha $=0.783$ with the high category

Data were analyzed using a two-way ANACOVA with initial critical thinking skills scores as covariates. Before ANACOVA, an assumption test was carried out. The covariance analysis was based on 3 assumption tests, namely 1) test of data distribution normality using Kolmogorov test and 
Shapiro-Wilk statistics; and 2) homogeneity test of variance between groups using Levene's Test of Equality of Error Variance; and 3) linearity test between covariates and dependent variables using test of linearity. Hypothesis testing is carried out at the 5\% significance level.

\section{RESULTS}

The results of descriptive analysis are presented in Table 3 . In this table, it appears that there is a descriptive difference in the average score of students' critical thinking skills who learn with PBFL and DFL, as well as between those who have low and high academic procrastination.

TABLE III. DESCRIPTIVE RESULTS

\begin{tabular}{|c|c|c|c|}
\hline & PBFL & DFL & \\
\hline LAP & $\begin{array}{l}\mathrm{M}_{11}=51.64 \\
\mathrm{SD}=13.34\end{array}$ & $\begin{aligned} \mathrm{M}_{12} & =38.68 \\
\mathrm{SD} & =8.09\end{aligned}$ & $\begin{array}{l}M_{1 t}=45.16 \\
S D=12.72\end{array}$ \\
\hline HAP & $\begin{array}{l}\mathrm{M}_{21}=40.14 \\
\mathrm{SD}=14.02\end{array}$ & $\begin{aligned} \mathrm{M}_{22} & =33.73 \\
\mathrm{SD} & =9.58\end{aligned}$ & $\begin{array}{l}\mathrm{M}_{2 \mathrm{t}}=36.94 \\
\mathrm{SD}=12.29\end{array}$ \\
\hline & $\begin{array}{l}\mathrm{M}_{\mathrm{t} 1}=45.89 \\
\mathrm{SD}=14.72\end{array}$ & $\begin{array}{c}\mathrm{M}_{\mathrm{t} 2}=36.21 \\
\mathrm{SD}=9.10\end{array}$ & \\
\hline
\end{tabular}

The data normality test based on the learning model is shown in Table 4 and based on academic procrastination in Table 5. Based on Table 4 and Table 5, it appears that the Pre critical thinking (PreCT) data and critical thinking (CT) data in all groups are normally distributed.

TABLE IV. TeSt OF NoRmality BASED ON MOdEL

\begin{tabular}{|c|c|c|c|c|c|c|c|}
\hline \multirow{2}{*}{ Source } & \multirow{2}{*}{ Model } & \multicolumn{3}{|c|}{ Kolmogorov-Smirnov } & \multicolumn{3}{|c|}{ Shapiro-Wilk } \\
\cline { 3 - 8 } & & Statistic & $\boldsymbol{d} \boldsymbol{f}$ & Sig. & Statistic & $\boldsymbol{d} \boldsymbol{f}$ & Sig. \\
\hline PreCT & PBFL & .112 & 44 & $.200^{*}$ & .978 & 44 & .546 \\
\hline & DFL & .093 & 44 & $.200^{*}$ & .977 & 44 & .522 \\
\hline CT & PBFL & .118 & 44 & .137 & .956 & 44 & .090 \\
\hline & DFL & .101 & 44 & $.200^{*}$ & .971 & 44 & .332 \\
\hline
\end{tabular}

TABLE V. TEST OF NORMALITY BASED ON ACADEMIC PROCRASTINATION

\begin{tabular}{|c|c|c|c|c|c|c|c|}
\hline \multirow{2}{*}{ Source } & \multirow{2}{*}{ Acaproc } & \multicolumn{2}{|c|}{ Kolmogorov-Smirnov } & \multicolumn{3}{c|}{ Shapiro-Wilk } \\
\cline { 3 - 8 } & & Statistic & $\boldsymbol{d} \boldsymbol{f}$ & Sig. & Statistic & $\boldsymbol{d} \boldsymbol{f}$ & Sig. \\
\hline PreCT & .086 & 44 & $.200^{*}$ & .967 & 44 & .245 & .086 \\
\hline & .107 & 44 & $.200^{*}$ & .968 & 44 & .250 & .107 \\
\hline $\mathrm{CT}$ & .150 & 44 & .014 & .970 & 44 & .315 & .150 \\
\hline & .109 & 44 & $.200^{*}$ & .967 & 44 & .238 & .109 \\
\hline
\end{tabular}

The results of the homogeneity analysis of variance are shown in Table 6, which states that the variance between treatment groups is homogeneous. Similarly, the compact test results as shown in Table 7 , found $F=2.513$ with the number sig. $=0.064$ which is greater than 0.05 , so the variance between groups is homogeneous.
TABLE VI. TEST OF HOMOGENEITY VARIANCE

\begin{tabular}{|l|l|c|c|l|c|}
\hline Source & Based On & $\begin{array}{c}\text { Levene } \\
\text { Statistic }\end{array}$ & Df1 & Df2 & Sig \\
\hline PreCT & Mean & 0.001 & 1 & 86 & 0.990 \\
\hline & Median & 0.002 & 1 & 86 & 0.964 \\
\hline & $\begin{array}{c}\text { Median and with } \\
\text { adjusted df }\end{array}$ & 0.002 & 1 & 85.818 & 0.964 \\
\hline CT & Trimed mean & 0.001 & 1 & 86 & 0.991 \\
\hline & Mean & 0.008 & 1 & 86 & 0.930 \\
\hline & Median & 0.001 & 1 & 86 & 0.977 \\
\hline & $\begin{array}{c}\text { Median and with } \\
\text { adjusted df }\end{array}$ & 0.001 & 1 & 85.210 & 0.977 \\
\hline & Trimed mean & 0.005 & 1 & 86 & 0.944 \\
\hline
\end{tabular}

TABLE VII. LEVENE'S TEST OF EQUALITY OF ERROR VARIANCES

\begin{tabular}{|c|c|c|c|}
\hline \multicolumn{4}{|c|}{ Dependent Variable: CT } \\
\hline $\boldsymbol{F}$ & $\boldsymbol{d} \boldsymbol{f 1}$ & $\boldsymbol{d f 2}$ & Sig. \\
\hline 2.513 & 3 & 84 & .064 \\
\hline
\end{tabular}

The result of the analysis showed that linearity statistics had the value of $F=31.2$ with the level of significance of 0.01 $<0.05$ and deviation from linearity statistics showed the value of $F=1.0$ with the level of significance of $0.5>0.05$, so that the covariate was linear to the dependent variable of critical thinking skill.

Because the assumption test has shown that ANACOVA can be done, the following is the result of the Test of between subject effects from ANACOVA, as in Table 8.

TABLE VIII. TEST OF BETWEEN SUBJECT EFFECTS

\begin{tabular}{|l|l|l|l|l|l|c|}
\hline \multicolumn{2}{|c|}{ Source } & $\begin{array}{c}\text { Type III Sum } \\
\text { of Squares }\end{array}$ & \multicolumn{1}{c|}{ df } & MS & F & Sig. \\
\hline PreCT & CT & 2260.163 & 1 & 2260.163 & $\begin{array}{l}21.08 \\
1\end{array}$ & 0.000 \\
\hline & Error & 8898.655 & 83 & $107.213^{\mathrm{b}}$ & & \\
\hline Model & CT & 1831.507 & 1 & 1831.507 & $\begin{array}{l}11.76 \\
9\end{array}$ & 0.006 \\
\hline & Error & 155.471 & .999 & $155.625^{\mathrm{c}}$ & & \\
\hline Acaproc & CT & 1086.911 & 1 & 1086.911 & 7.006 & 0.025 \\
\hline & Error & 157.140 & 1.013 & $155.144^{\mathrm{d}}$ & & \\
\hline $\begin{array}{l}\text { Model* } \\
\text { Acaproc }\end{array}$ & CT & 155.590 & 1 & 155.590 & 1.451 & 0.232 \\
\hline & Error & 8898.655 & 83 & $107.213^{\mathrm{b}}$ & & \\
\hline
\end{tabular}

Based on Table 8, the following findings can be presented. 1) From the source of the influence of PreCT on CT, it appears that the statistical value is $F=21.081$ with sig $=0.001$. Number sig. this is less than 0.05 , so the preCT covariate significantly affects CT. 2) Based on the source of the influence of the model on $\mathrm{CT}$, it is revealed that the statistical value of $\mathrm{F}=$ 11,769 with sig $=0.006$. Number sig. is $<0.05$, so it can be stated that there is a difference in the effect between PBFL and DFL on CT.

TABLE IX. COMPARISON MEAN BASED ON MODEL

\begin{tabular}{|l|l|l|l|l|}
\hline Source & Mean & SD & \multicolumn{1}{|c|}{ Lower Bound } & Upper Bound \\
\hline PBFL & 45.89 & 14.72 & 42.507 & 48.721 \\
\hline DFL & 36.21 & 9.10 & 33.370 & 39.584 \\
\hline
\end{tabular}


By comparing the mean CT values of PBFL and DFL in Table 9, it appears that PBFL has a higher effect than DFL in achieving CT. Comparison mean based on Acaproc can be seen in table 10 .

TABLE X. COMPARISON MEAN BASED ON ACAPROC

\begin{tabular}{|l|c|c|c|c|}
\hline Source & Mean & SD & Lower Bound & Upper Bound \\
\hline LAP & 45.16 & 12.72 & 41.468 & 47.697 \\
\hline HAP & 36.94 & 12.29 & 34.394 & 40.623 \\
\hline
\end{tabular}

3) Based on the source of acaproc's influence (Table 8) on $\mathrm{CT}$, it was found that $\mathrm{F}=7.006$ with the number sig. $=0.025$. Number sig. is $<0.05$, so it is stated that there is a difference in the effect between LAP and HAP on CT. By comparing the mean CT values of LAP and HAP, it appears that students who have LAP tend to be able to achieve higher CT than those who have HAP. 4) Based on the source of influence of the * acaproc model (Table 8 ), it appears that $\mathrm{F}=1.451$ with the number sig. $=0.232$. Number sig. $>0.05$, so it can be stated that there is no interactive effect between learning models and academic procrastination on critical thinking skills. The interaction profile is not significant at the sig. $5 \%$ is shown in Figure 1.

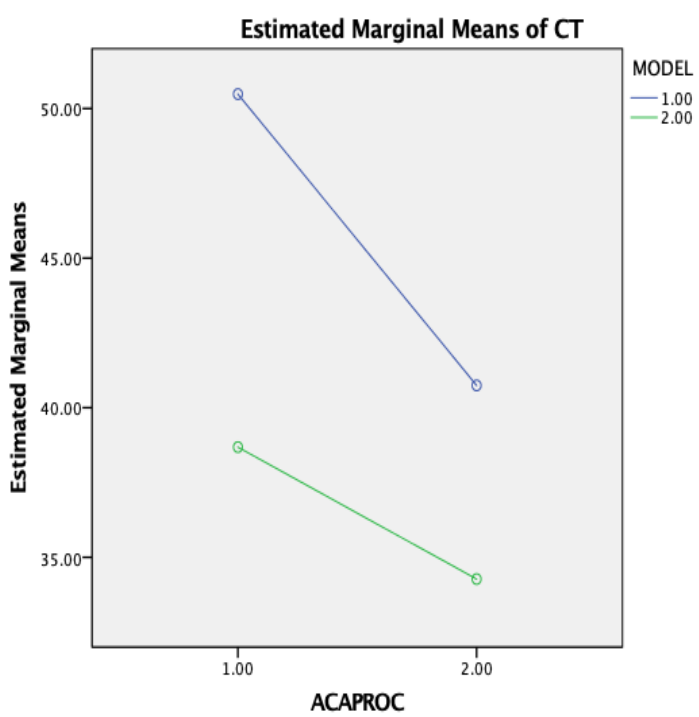

Covariates appearing in the model are evaluated at the following values: PRECT $=23.1364$

Fig. 1. Profile of interaction between learning models and academic procrastination, not significant at 5\% significant level.

\section{DISCUSSION}

Physics learning in senior high school which tends to use the direct learning (DL) model should be immediately abandoned, especially in an effort to facilitate students in developing critical thinking skills. One of its substitutes is the problem-based learning (PBL) model. The two models can be integrated as pedagogical content of flipped learning (FL), so that the two learning models in this study are termed problem- based flipped learning (PBFL) and direct flipped learning (DFL). The purpose of this study was to analyze the differences in the main effect and interaction between PBFL and DFL on students' critical thinking skills viewed from students' academic procrastination attitudes in learning physics in senior high school.

The results of the analysis of the main effect of the learning model show that there is a significant difference in the effect of PBFL and DFL on students' critical thinking skills. Students who studied with the PBFL model showed a significantly higher critical thinking skill than those who studied with the DFL model. The results of this study are in accordance with the results of previous studies [10,42-44]. The advantage of the PBFL model compared to the DFL model is because in the PBFL model students are more involved in learning to empower critical, analytical, systematic and logical thinking to determine alternative problem solving through empirical data exploration to foster scientific attitudes [29]. Although the PBFL model is superior to the DFL model in achieving critical thinking, the results shown are inadequate. The results on the PBFL are indicated by an average value of $\mathrm{M}=45.89$; $\mathrm{SD}=$ 14.72 in the low category, the more so the results shown by the DFL model are $\mathrm{M}=\mathrm{Mt} 2=36.21 ; \mathrm{SD}=9.10$ in the very low category. This result is relatively greater than the results of previous studies [10], which in the PBL model only achieved critical thinking skills with an average value of $\mathrm{M}=36.86$; $\mathrm{SD}$ $=0.561$, very low category, and DL model with $\mathrm{M}=33.02 ; \mathrm{SD}$ $=0.561$, very low category. This is because students are not used to learning to solve non-routine problems which are packaged in the PBFL model. These results indicate that the PBL or PBFL model must be continuously implemented intensively in learning physics in order to facilitate students to achieve more optimal critical thinking skills.

The results of the analysis of the main effect of academic procrastination attitudes show that there is a significant difference in the effect of low academic procrastination (LAP) and high academic procrastination (HAP) on students' critical thinking skills in learning physics in senior high school. Students who have LAP show critical thinking skills is significantly higher than students who have HAP. The results of this study are in accordance with previous studies [28] Quantitatively, the average value of critical thinking skills that can be achieved by students who have LAP is $\mathrm{M}=45.62$ with $\mathrm{SD}=12.72$, in the low category, while those achieved by students who have HAP are $\mathrm{M}=36.94 ; \mathrm{SD}=12.29$ with very low category. In physics learning in high school, students who have more LAP who have HAP should be guided continuously not to procrastinate in doing their study assignments.

The results of the analysis of the interactive effect of the learning model (PBFL v.s DFL) and academic procrastination (LAP v.s HAP) on critical thinking skills show that in achieving critical thinking skills, the two learning models do not interact significantly. These results indicate that both the PBFL and the DFL models accommodate students' LAP and HAP in physics learning. These results reinforce the thesis that students undoubtedly need guidance in order to minimize their 
academic procrastination attitudes in learning physics in senior high school.

\section{CONCLUSION AND SUGGeSTION}

There is a significant difference in the effect between PBFL and DFL on students' critical thinking skills. Students who learn with the PBFL model show a significantly higher critical thinking skill than those who learn with the DFL model. The implication is that the PBL or PBFL model must be continuously and intensively implemented in physics learning in order to facilitate students to achieve more optimal critical thinking skills.

There is a significant difference in the influence between low academic procrastination (LAP) and high academic procrastination (HAP) on students' critical thinking skills in learning physics in senior high school. Students who have LAP show critical thinking skills is significantly higher than that achieved by students who have HAP. In physics learning in high school, students who have more LAP or HAP should be guided continuously not to procrastinate in doing their study assignments.

There is no interactive effect between the learning model (PBFL v.s DFL) and academic procrastination (LAP v.s HAP) on critical thinking skills. Both PBFL and DFL models accommodate students' LAP and HAP in physics learning. The implication is that students undoubtedly need guidance in order to minimize their academic procrastination attitudes in learning physics in senior high school.

\section{ACKNOWLEDGMENT}

Thank you to the Principal of SMAN 2 Semarapura Klungkung Bali for the permission given to do the research, thanks to Gede Bayu Adipura and Kadek Nopi Aryati, they are the Physics Teachers of SMAN 2 Semarapura Klungkung Bali who became collaborators of this research. Lastly, thanks to the Ganesha University of Education Research Institute for the fees provided.

\section{REFERENCES}

[1] Partnership for 21st Century Learning, "P21 Partnership for 21st Century Learning. Partnership for 21st Century Learning”, Washington DC: Author, 2015

[2] A.R. Sirait, B. Sinaga, and Mulyono, "Analysis difficulty of mathematical creative thinking ability reviewed from learning styles through problem based learning," Advances in Social Sciences Research Journal, vol. 5, pp. 395-404, 2018.

[3] Firdaus, I. Kailani, M.N.B. Bakar, and Bakry, "Developing critical thinking skills of students in mathematics learning', Journal of Education and Learning, vol. 9, pp. 226-236, 2015.

[4] E.E. Rohaeti, "Critical and creative mathematical thinking of junior high school students”, Educationist, vol. 4, pp. 99-106, 2010.

[5] I.W. Santyasa, I.W.S. Warpala, and I K. Sudarma, "The power of group investigation model on students critical thinking, attitude, and character in learning physics", Advances in Social Science, Education and Humanities Research, vol. 274, pp. 101-106, 2018.
[6] S. Winarno, K.S. Muthu, and L.S. Ling, "Direct problem-based learning (DPBL): A framework for integrating direct instruction and problembased learning approach", International Education Studies, vol. 11, pp. 119-126, 2018

[7] L.D. Hammond, B. Barron, P.D. Pearson, A.H. Schoenfeld, E.K. Stage, T.D. Zimmerman, and J.L. Tilson, Powerful learning: What we know about teaching for understanding, New York: John Wiley \& Sons, 2015.

[8] Prayekti, "Effects of problem-based learning model versus expository model and motivation to achieve for student's physics learning result of senior high school at class XI", Journal of Education and Practice, vol. 17, pp. 30-37, 2016

[9] M.S. Aziz, A.N.Md. Zain, M.A.B. Samsudin, and S.B. Saleh, "The effects of problem-based learning on self-directed learning skills among physics undergraduates," International Journal of Academic Research in Progressive Education and Development January 2014, vol. 3, pp. 126 137,2014

[10] I.W. Santyasa, G.S. Santyadiputra, and M. Juniantari, "Problem-based learning model versus direct instruction in achieving critical thinking ability viewed from students' social attitude in learning physics,' Advances in Social Science, Education and Humanities Research, vol 335, pp. 633-644, 2019

[11] Sahyar, R.A. Sani, and T. Malau, "The effect of problem-based learning model and self-regulated learning toward physics problem solving ability of students at senior high school", American Journal of Educational Research, vol. 5, pp. 279-283, 2017.

[12] R. Afrilyasanti, B.Y. Cahyono, and U.P. Astuti, "Indonesian EFL students' perceptions on the implementation of flipped classroom model Journal of Language Teaching and Research, vol. 8, pp. 476-484, 2017.

[13] J.L. Bishop and M.A. Verlager, "The flipped classroom: A survey of the research", 120th ASEE Annual Conference \& Exposition, 2013.

[14] C.J. Brame, "Flipping the classroom", 2013. [Online] Retrieved from: https://cft.vanderbilt.edu/guides-sub-pages/flipping-the-classroom/

[15] L. Drake, M. Keyser, and R. Jacobwitz, "The flipped classroom, an approach to teaching and learning", A 2020 Vision for Public Education in Ultster Country, 2016.

[16] R. Fedistia, E. Musdi, and Yerizon, "Advantages and challenges of the flipped classroom application-based learning in enhancing 10th grade senior high school students' reasoning ability", International Journal of Scientific \& Technology Research, Vol. 8, No. 8, pp. 916-919, 2019

[17] N. Hamdan, M. Katherine, M. A. Kari, and M. Patrick, "A review of flipped learning", Flipped Learning Network. Available at: https://flippedlearning.org/wpcontent/uploads/2016/07/LitReview_Flipp edLearning.pdf, 2013

[18] J. L. Jensen, T. A. Kummer, and P. D. D. M. Godoy, "Improvements from a flipped classroom may simply be the fruits of active learning", CBE Life Sciences Education, Vol. 14, No. 1, 2015.

[19] X. Hu, H. Zhang, Y. Song, C. Wu, Q. Yang, Z. Shi, X. Zhang, and W. Chen, "Implementation of flipped classroom combined with problembased learning: An approach to promote learning about hyperthyroidism in the endocrinology internship", BMC Medical Education, Vol. 19, Np. 290, pp. 1-8, 2019.

[20] A. S. Albalawi, "The effect of using flipped classroom in teaching calculus on students achievement at University of Tabuk", International Journal of Research in Education and Science (IJRES), Vol. 4, No. 1, pp. 198-207, 2018.

[21] S. Dehghanzadeh and F. Jafaraghaie, "Comparing the effects of traditional lecture and flipped classroom on nursing students' critical thinking disposition: A quasi-experimental study", International Journal for Helth Care Education, Vol. 71, pp. 151-156, 2018.

[22] D. J. Peterson, "The flipped classroom improves student achievemen and course satisfaction in a statistics course: A quasi-experimental study", Society for the Teaching of Psychology, Vol. 43, No. 1, pp. 10$15,2016$. 
[23] D. Saglam and A. Arslan, "The effect of flipped classroom on the academic achievement and attitude of higher education students", World Journal of Education, Vol. 8, No. 4, pp. 170-176, 2018.

[24] D. S. Ackerman and B. L. Gross, "My instructor made me do it: Task characteristics of procrastination", J. Market. Educ. Vol. 27, No. 1, pp. 5-13, 2005

[25] E. D. Deemer, J. L. Smith, A. N. Carroll, and J. P. Carpenter, “Academic procrastination in STEM: Interactive effects of stereotype threat and achievement goals", The Career Development Quarterly, Vol. 62, pp. 143-155, 2014.

[26] A. A. Ojo, "The impact of procrastination on students academic performance in secondary schools", International Journal of Sociology and Anthropology Research, Vol. 5, No. 1, pp. 17-22, 2019.

[27] A. Bakhshayesh, H. Radmanesh, and K. B. Bafrooee, "Investigating relation between academic procrastination and math performance of students in first year of high school", Journal of Educational and Management Studies, Vol. 6, No. 3, pp. 62-67, 2016.

[28] I. W. Santyasa, N. K. Rapi, and I W. W. Sara. "Project Based Learning and Academic Procrastination of Students in Learning Physics", International Journal of Instruction, Vol. 13, No. 1, pp. 489-508, 2020.

[29] I. W. Santyasa. "Pembelajaran inovatif", Singaraja: Undiksha Pres, 2017.

[30] G. S. Selcuk, "The effects of problem-based learning on pre-service teachers' achievement, approaches and attitudes towards learning physics", International Journal of the Physical Sciences, Vol. 5, No. 6, pp. 711-723, 2010.

[31] D. P. Maloney, "Research on problem solving in physics", In D. L Gabel (Ed.): Handbook of research in science teaching and learning, New York: Macmillian, 1994, pp. 327-354.

[32] K. A. Abou-Elhamd, U. M. Rashad, and A. I. Al-Sultan, "Applying problem-based learning to otolaryngology teaching", The Journal of Laryngology \& Otology, Vol. 125, No. 2, pp. 117-120, 2011.

[33] Y. M. Lee, K. V. Mann, and B. W. Frank, "What drives students' selfdirected learning in a hybrid PBL curriculum", Adv in Health Sci Educ, Vol. 15, No. 3, pp. 425-437, 2010.

[34] S. Chakravarthi, "Implementation of PBL curriculum involving multiple disciplines in undergraduate medical education programme", International Education Studies, Vol. 3, No. 1, pp. 165-169, 2010.
[35] A. Efendioglu, "Problem-based learning environment in basic computer course: Pre-service teachers' achievement and key factors for learning". Journal of International Education Research, Vol. 3, No. 1, pp. 205-216, 2015 .

[36] A. Luke, "On explicit and direct instruction", Australian Literacy Educator's Association, More alea 'hot topics' at www.alea.edu.au, 2014.

[37] J. R. Ferrari, J. L. Johnson, and W. G. McCown, "Procrastination and task avoidance theory, research, and treatment", New York, NY: Springer, 1995.

[38] M. R. A. Wulandari, "Pengaruh kecerdasan emosional, perilaku belajar dan prokrastinasi akademik terhadap prestasi belajar mahasiswa", Skripsi Online, 2016.

[39] R. H. Ennis, "The nature of critical thinking: Outlines of general critical thinking dispositions and abilities", Online article. http://criticalthinking.net/wp-content/uploads/2018/01/The-Nature-ofCritical-Thinking.pdf, 2013.

[40] M. KARAKOÇ, "The significance of critical thinking ability in terms of education", International Journal of Humanities and Social Science, Vol. 6, No. 7, pp. 81-84, 2016.

[41] W. A. Mehrens and I. J. Lehmann, "Measurement and evaluation in education and psychology", New York: Holt, Rinehart and Winston, 1984.

[42] R. A. Oktavia, Usmeldi, and Yohandri, "Development of Physics Learning Material Based on Problem Based Learning by Integrating Local Wisdom West Sumatra to Improve Critical Thinking Ability of Students", International Journal of Progressive Sciences and Technologies (IJPSAT), Vol. 6, No. 2, pp. 544-553, 2018.

[43] M. Padmadewa and H. Ismoyo, "Effect of problem-based learning on improvement physics achievement and critical thinking of senior high school student", Journal of Baltic Science Education, Vol. 16, No. 5, pp. 761-780, 2017.

[44] R. Sujanem, S. Poedjiastuti, and B. Jatmiko, "The Effectiveness of problem-based hybrid learning model in physics teaching to enhance critical thinking of the students of SMAN", International Conference on Mathematics and Natural Sciences (IConMNS 2017), pp. 1-6, IOP Conf. Series: Journal of Physics: Conf. Series 1040 (2018) 012040, 2018. 